\title{
Sistem Akumulasi Sanksi: Usulan Perubahan Kategorisasi dan Akumulasi Penetapan Sanksi untuk Pelanggaran Etik Kedokteran
}

\author{
Pukovisa Prawiroharjo ${ }^{\mathrm{T}, 2}$, Agus Purwadianto ${ }^{\mathrm{1}, 3}$, Yuli Budiningsih ${ }^{\mathrm{1}, 3}$ \\ ${ }^{1}$ Majelis Kehormatan Etik Kedokteran Pengurus Besar Ikatan Dokter Indonesia \\ ${ }^{2}$ Departemen Neurologi, Fakultas Kedokteran Universitas Indonesia/Rumah Sakit Cipto Mangunkusumo, Jakarta \\ ${ }^{3}$ Departemen Ilmu Kedokteran Forensik dan Medikolegal, Fakultas Kedokteran Universitas Indonesia/Rumah Sakit Cipto Mangunkusumo
}

\section{Kata Kunci \\ etik, sanksi, sistem \\ Korespondensi \\ pukovisa@ui.ac.id \\ Publikasi \\ (C) $2018 \mathrm{JEKI} /$ ilmiah.id \\ DOI \\ I0.26880/jeki.v2i3.2I}

Tanggal masuk: 3 Juli 2018

Tanggal ditelaah: I Oktober 2018

Tanggal diterima: 5 Oktober 2018

Tanggal publikasi: 24 Oktober 2018

\begin{abstract}
Abstrak Suatu pelanggaran etik yang dinilai berat senantiasa tersusun atas akumulasi dan eskalasi dari perilaku pelanggaran etik dengan bobot di bawahnya (sedang dan ringan). Oleh karena itu, penetapan sanksi etik lebih menjunjung keadilan jika juga diberlakukan akumulatif dan eskalatif. Hal ini memastikan bahwa setiap pelanggaran etik akan mendapatkan sanksi yang berfokus pada pembinaan perilaku, karena tujuan utama dari pemberian sanksi sejatinya ialah perubahan karakter dan perilaku untuk menjadi lebih baik, demikian pula tujuan utama Majelis Kehormatan Etik Kedokteran Ikatan Dokter Indonesia (MKEK IDI) yang adalah pembinaan perilaku dan karakter dokter menjadi lebih mulia. Oleh karena itu, kami mengusulkan pembagian sanksi etik menjadi tiga kategori: kategori I (pembinaan perilaku), kategori 2 (penginsafan tanpa pemecatan), dan kategori 3 (penginsafan dengan pemecatan sementara), yang cocok untuk masing-masing pelanggaran etik ringan, sedang, dan berat, serta sistem pemberlakuannya yang akumulatif.
\end{abstract}

\begin{abstract}
A severe ethical violation is always built up from accumulation and escalation of other lesser ethical violations (minor and moderate). Therefore, it is more just if ethical sanctions are imposed cumulatively and escalatingly as well. This ensures that every ethical violation is sanctioned with focus on behavioral guidance, as the main objective of sanctions is improving character and behavior, and the main purpose of Medical Ethics Council of Honor of Indonesian Doctors Association (MKEK IDI) is to develop honorable behavior and character of doctors. Therefore, we propose the categorization of ethical sanctions into three categories with accumulative enforcement system: category I (behavioral guidance), category 2 (detention without dismissal), and category 3 (detention with temporary dismissal), which are suitable for minor, moderate, and severe ethical violations, respectively.
\end{abstract}

\section{PENDAHULUAN}

Profesi dokter, sebagai suatu profesi yang memiliki berbagai tradisi luhur dan berbuah penghormatan yang tinggi di masyarakat, perlu tetap melestarikan tradisi yang membanggakan tersebut untuk menjaga kepercayaan masyarakat yang senantiasa memberi penghormatan tinggi hingga kini. Namun di sisi lain, dokter tetaplah manusia yang terikat ungkapan klise, tempatnya salah dan lupa. Maka pembentukan dan penjagaan karakter dokter agar tetap berjalan lurus menurut nilai-nilai luhur profesi tidak dapat semata-mata dibebankan hanya pada proses perkuliahan di fakultas kedokteran. Setelah lulus dan ditahbiskan menjadi dokter, peran pengawasan, penjagaan, dan pembentukan karakter luhur dokter beralih dari universitas ke organisasi profesi. Salah satu organ dalam organisasi profesi kedokteran Indonesia yang dibentuk dan diamanatkan untuk mengawasi, menjaga, dan membentuk karakter luhur dokter ialah Majelis Kehormatan Etik Kedokteran (MKEK). ${ }^{1}$ 
Tujuan inilah yang menjadi roh dari perputaran kerja dan pengabdian sebagian sejawat yang diamanahkan di MKEK. Maka sudah sepatutnyalah seluruh aktivitas yang dilakukan MKEK memiliki sangkutan muara pada pembinaan perilaku profesionalisme seluruh dokter Indonesia. Tak terkecuali adalah aktivitas kemahkamahan, yang menjadi wewenang khas dan otonom pada MKEK melaksanakan yurisdiksi penatalaksanaan aduan masyarakat terkait etika seorang atau sekelompok dokter Indonesia. ${ }^{1,2}$

Untuk mempertahankan roh penjagaan dan pembentukan karakter luhur dokter tersebut, aktivitas kemahkamahan dan pembinaan MKEK perlu didesain dengan sedikit perubahan dari tata kelola lama yang tertuang dalam Pedoman Organisasi dan Tatalaksana Kerja MKEK ${ }^{2}$ sehingga dapat lebih menunjang dan memastikan adanya pembinaan perilaku yang dapat menyertai sanksi yang bersifat penginsafan hingga pemecatan. ${ }^{3}$

\section{HASIL DAN PEMBAHASAN}

\section{Gradasi Pelanggaran Etik Berat, Sedang, dan Ringan Merupakan Proses Akumulasi, Eskalasi, dan Keterbiasaan}

Dari pengalaman menelaah kasus yang masuk ke MKEK, terungkap bahwa umumnya mereka yang kemudian diberi sanksi pelanggaran etik berat telah terbiasa melakukan pelanggaran etik ringan dan sedang sebelumnya, baik disadari maupun tidak. Hal sebaliknya tentu saja menjadi pertimbangan Majelis Pemeriksa MKEK yang menangani dugaan pelanggaran etik; jika dokter teradu riwayatnya bersih dan tak pernah terindikasi melanggar etik ringan dan sedang sebelumnya, maka sang dokter teradu tersebut kecil kemungkinannya dijatuhi sanksi pelanggaran etik berat. Umumnya pelanggaran etik berat sangat terkait dengan karakter dan perilaku yang dalam kajiannya tampak sangat menyimpang dari ketentuan yang diharapkan dalam Kode Etik Kedokteran Indonesia, baik mengenai etika dokter-pasien, etika kesejawatan, etika dengan organisasi profesi, dan sebagainya. ${ }^{2,4}$ Demikian pula dalam perkara yang diberi sanksi pelanggaran etik sedang, umumnya terungkap bahwa dokter teradu tersebut sering melakukan pelanggaran etik ringan, baik disadari maupun tidak, dan sudah tentu Majelis Pemeriksa MKEK dalam pertimbangannya melihat riwayat dokter teradu tersebut.

Gradasi tersebut nampak sekali terbangun dari akumulasi pelanggaran etik sebelumnya. Kemudian karena mulai terbiasa, merasa aman dan nyaman dengan akumulasi itu, terjadilah eskalasi pelanggaran etik menjadi semakin berat skalanya. Hal ini dapat dijelaskan pada Gambar 1, di mana tampak pelanggaran etik berat itu akan terbangun dari akumulasi dan eskalasi pelanggaran etik ringan dan sedang. Sementara pelanggaran etik sedang juga terbangun dari akumulasi dan eskalasi pelanggaran etik ringan. Hal ini diakibatkan oleh eratnya kaitan etika dengan karakter personal dan bagaimana karakter tersebut mengekspresikan dirinya pada tugas dan tanggung jawab profesi kedokteran.

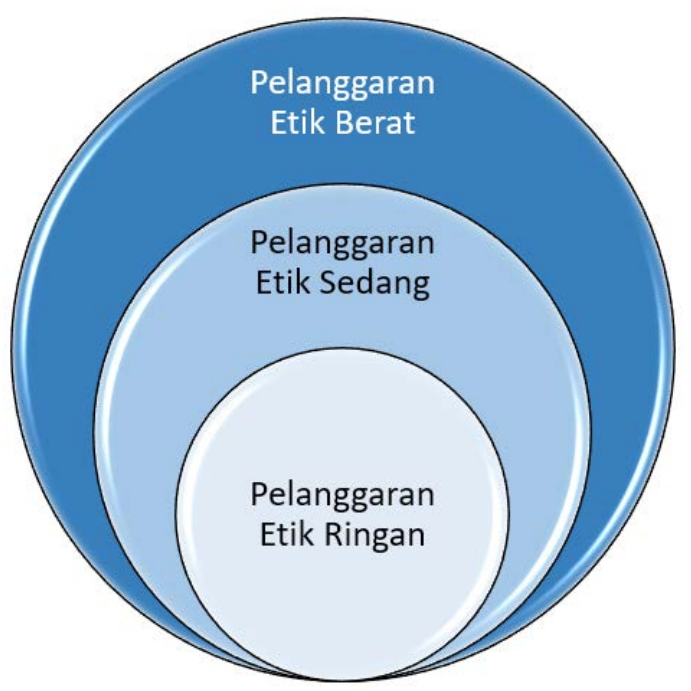

\section{Gambar 1 Tiga orbit kategori pdanggaran eik keddkteran.}

Oleh karenaitu, gradasi dalam memutuskan suatu pelanggaran etik tersebut berat, sedang, dan ringan perlu sangat mempertimbangkan proses akumulasi dan eskalasi dari pelanggaranpelanggaran etik lainnya di dalam maupun di luar konteks perkara yang diadukan. Akibatnya, keputusan MKEK yang dihasilkan dapat merefleksikan karakter dokter teradu yang terbangun dari berbagai perbuatan dan kebiasaan yang memiliki nilai moral sehari-hari. 


\section{Pemberian Sanksi Etik Mempertimbangkan Gradasi Pelanggaran Etik Berdasarkan Akumulasi dan Eskalasi}

Sesuai dengan proses akumulasi dan eskalasi yang kemudian menjadi pelanggaran etik berat/sedang, maka konstruksi pemikiran untuk pemberian sanksi etik juga perlu mempertimbangkan prinsip akumulasi dan eskalasi tersebut. Oleh karena itu, perlu dikonstruksi sanksi yang cocok untuk pelanggaran etik ringan, yang sanksi tersebut murni bertujuan untuk membina perilaku dokter teradu tersebut. Kemudian dikonstruksi sanksi yang memadai untuk pelanggaran etik sedang dan berat, dengan tujuan memberikan efek penginsafan agar kesalahan serupa tidak pernah terpikirkan untuk diulangi kembali di masa depan. Dengan mempertimbangkan proses akumulasi dan eskalasi sebagai proses kompleks dalam karakter dokter teradu dari sisi pelanggaran yang dilakukannya, maka pemberian sanksi juga perlu dilakukan secara akumulasi. Hal ini dimaksudkan agar tujuan dari setiap strata sanksi tersebut, yaitu pembinaan dan penginsafan, dapat efektif sehingga dapat diharapkan terjadi perubahan karakter dan sikap dari seorang dokter pasca menjalani sanksi etik. Itulah tujuan utama dari proses yang ada di MKEK yang berorientasi pembinaan dan bukan pembinasaan. ${ }^{3}$

\section{Sistem Tiga Orbit: Usulan Perubahan Kategorisasi Penetapan Sanksi Untuk Pelanggaran Etik Kedokteran}

Sesuai dengan dibaginya tiga kategori gradasi pelanggaran etik sebelumnya berupa pelanggaran etik ringan, sedang, dan berat, maka dalam inventarisasi alternatif sanksi yang diberikan melalui usulan ini juga perlu dibagi tiga kategori. Usulan tersebut ialah:

1. Sanksi kategori 1, terdiri dari berbagai sanksi yang memiliki sifat murni bertujuan melakukan pembinaan perilaku terhadap pelanggarnya.

2. Sanksi kategori 2, terdiri dari sanksi yang memiliki sifat penginsafan terhadap pelanggarnya, namun tanpa konsekuensi pemecatan dari keanggotaan yang berimplikasi pada kehilangan hak dan wewenangnya sebagai dokter secara total pada kurun waktu tertentu.

3. Sanksi kategori 3, terdiri dari sanksi yang memiliki sifat penginsafan berupa pemecatan sementara dari keanggotaan, yang berimplikasi pada kehilangan hak dan wewenangnya sebagai dokter secara total pada kurun waktu tertentu.

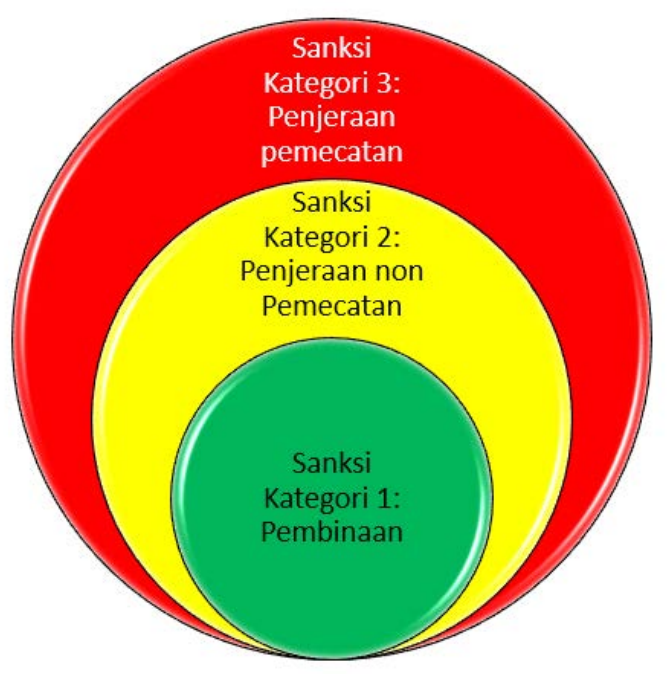

\section{Gambar 2. Tiga orbit kategorisasi sanksi MKEK.}

Kemudian sebagaimana dijelaskan sebelumnya tentang akumulasi dan eskalasi pelanggaran etik, usulan 3 orbit ini juga memiliki format pemberian sanksi yang berlaku akumulatif. Akibatnya, seorang yang diputuskan melanggar etik berat akan menerima masingmasing minimal satu buah sanksi dari kategori 1 (pembinaan perilaku), satu buah sanksi dari kategori 2 (penginsafan tanpa pemecatan), dan satu buah sanksi dari kategori 3 (penginsafan dengan pemecatan). Dapat kita refleksikan apabila seorang yang melanggar etik berat hanya diberi sanksi pemecatan sementara misalnya, lalu tidak ada ketetapan baginya untuk diikutkan program pembinaan perilaku (sanksi kategori 1), maka bagaimana peluang sejawat tersebut untuk mengalami perubahan pada perilakunya dan tidak mengulangi kesalahan yang sama di masa mendatang? Oleh karena itu, sistem akumulasi sanksi ini dinilai lebih bijak.

\section{Sanksi Kategori 1: Metode dan Penerapannya}

Metode-metode apa sajakah yang layak merepresentasikan esensi tujuan sanksi kategori 
1 yang bersifat murni pembinaan perilaku etis dan profesional ini? Usulan kami adalah sanksi tersebut bersifat aktif membantu pembentukan karakter dan perilaku teradu ke arah yang lebih baik, dan bukan pasif sebagaimana dijabarkan Ortala MKEK 2008 sebelumnya, seperti peringatan lisan dan peringatan tertulis. ${ }^{2}$ Beberapa metode yang dapat dipertimbangkan untuk mewakili tujuan pembinaan perilaku ialah:

1. Membuat refleksi diri dan janji kepada diri sendiri secara tertulis.

2. Mengikuti workshop etik yang ditentukan MKEK.

3. Mengikuti modul etik yang sedang berjalan di FK yang ditunjuk MKEK.

4. Mengikuti program membayangi panutan selama 3 (tiga) bulan.

5. Kerja sosial pengabdian profesi selama 3 (tiga)

6. Surat permohonan maaf dan atau pelurusan berita jika menyangkut informasi di media massa atau media sosial sambil aktif meluruskan pemahaman masyarakat umum terkait informasi keliru yang disebarkan.

7. Dan metode-metode lain yang dianggap baik dan cocok menjadi representasi esensi tujuan sanksi yaitu murni pembinaan perilaku.

Untuk penerapan sanksi kategori 1 ini akan menjadi wilayah Divisi Pembinaan MKEK sesuai yurisdiksi yang ditetapkan Ortala MKEK. ${ }^{2}$ Jika Majelis Pemeriksa menetapkan suatu pelanggaran etik yang terjadi masuk dalam kategori ringan, dan hanya sanksi ini saja yang diputuskan, maka sebaiknya keputusan disampaikan secara tertutup, sebab pembukaan hasil putusan berisiko memunculkan pembesarbesaran masalah oleh pihak luar yang tidak bertanggung jawab dan bermaksud menjatuhkan dokter yang terkait. Lain halnya bila pelanggaran etik tersebut memang harus dibuka ke pihak lain, antara lain bila merupakan penyebaran berita bohong (hoax) atau merugikan profesi kedokteran di mata publik. ${ }^{5}$

\section{Sanksi Kategori 2: Metode dan Penerapannya}

Sanksi kategori 2 memiliki tujuan memberi efek penginsafan namun tidak sampai pada pemecatan keanggotaan. Beberapa metode yang relevan untuk sanksi kategori 2 yang dapat dipertimbangkan adalah sebagai berikut:

a. Mengikuti program membayangi panutan selama 4-12 bulan.

b. Kerja sosial pengabdian profesi selama 4-12 bulan.

c. Pemberhentian sementara dari jabatan di IDI dan organisasi di bawah IDI serta pelarangan menjabat untuk 1 periode kepengurusan pasca keputusan.

d. Dan metode lain yang dianggap baik dan cocok menjadi representasi esensi tujuan sanksi yaitu penginsafan tanpa pemecatan keanggotaan.

Sesuai dengan prinsip akumulasi-eskalasi, mereka yang diberikan sanksi kategori 2 pastilah juga akan menjalani minimal satu bentuk sanksi kategori 1. Bentuk sanksi yang ada perlu untuk dicermati Majelis Pemeriksa agar dapat bersinergi membuahkan penginsafan dan perubahan perilaku yang lebih baik di masa mendatang.

Untuk sifat keterbukaan putusan sanksi kategori 2 ini tentu diperlukan hanya untuk kalangan terbatas saja karena eksekusi sanksi ini melibatkan kerjasama dengan pihak luar. ${ }^{5}$

\section{Penerapan Sanksi Kategori 3}

Sanksi kategori 3 ialah kategori sanksi terberat dari seluruh kategori yang ada, memiliki tujuan memberikan penginsafan yang dipandang perlu sampai terpaksa dilakukan pemecatan keanggotaan. Konsekuensi dari pemecatan keanggotaan ialah dokter yang menerima sanksi akan kehilangan segenap hak, kewenangan, dan klausul persyaratan sebagai dokter Indonesia dan anggota IDI selama kurun waktu tertentu. akan dicabut seluruh hak dan kewenangannya sebagai dokter dan anggota IDI. Hilangnya hak dan kewenangan tersebut berdampak pada: (1) kehilangan hak dan kewenangan melakukan praktik kedokteran, termasuk dicabut sementara seluruh rekomendasi izin praktik yang akan ditindaklanjuti kemudian oleh otoritas penerbit izin praktik untuk menonaktifkan sementara Surat Izin Praktik yang bersangkutan, (2) kehilangan hak dan kewenangan menjadi pengurus dan anggota IDI dan seluruh 
organisasi di bawah IDI termasuk Perhimpunan Dokter Spesialis (PDSp), Perhimpunan Dokter Pelayanan Primer (PDPP), dan Perhimpunan Dokter keseminatan tertentu (PDSm), (3) kehilangan hak dan kewenangan menyandang suatu jabatan publik atau organisasi yang menyaratkan dijabat oleh seorang dokter aktif yang akan ditindaklanjuti instansi/organisasi terkait, (4) surat tanda registrasi (STR) dan status di Konsil Kedokteran Indonesia (KKI) menjadi non-aktif yang akan ditindaklanjuti oleh KKI.

Pemecatan keanggotaan yang dapat diputuskan oleh Majelis Pemeriksa MKEK ialah bersifat sementara. Durasi pemecatan keanggotaan dapat diputuskan secara bijaksana oleh Majelis Pemeriksa dengan mempertimbangkan seluruh aspek dengan alternatif kurun waktu antara 3-12 bulan.

Majelis Pemeriksa dapat mengajukan rekomendasi pemecatan keanggotaan tetap sebagai pelengkap (addendum) dari penjatuhan sanksi pemecatan keanggotaan sementara. Rekomendasi pemecatan keanggotaan tetap tersebut akan diputuskan di Muktamar IDI sebagai forum tertinggi pembuat keputusan di IDI.

\section{Usulan Sanksi Akumulatif 3 Orbit: Lebih Beratkah dari Format Sanksi Terdahulu?}

Lalu apakah sanksi akumulatif ini berarti bahwa sanksi yang ditawarkan lebih berat dibandingkan format sanksi terdahulu? Tidakkah nanti sejawat akan mengajukan keberatan karena mekanisme yang semakin berat dari akumulasi sanksi ini?

Untuk diketahui, pada format sanksi yang tercantum pada Pedoman Organisasi dan Tatalaksana Kerja MKEK IDI tahun 2008 memangtidakdijelaskantegasbagaimanarentang variasi sanksi dapat diberikan dalam berbagai kategori pelanggaran etik. Hanya satu jenis sanksi yang memuat perbedaan antarkategori pelanggaran etik yaitu bentuk sanksi pemecatan anggota sementara. Dinyatakan Ortala MKEK bahwasanya pelanggaran etik ringan dapat dikenai sanksi pemecatan anggota selama 3 (tiga) bulan, pelanggaran etik sedang dapat dikenai 6 (enam) bulan, dan pelanggaran etik berat dikenai 12 (duabelas) bulan. ${ }^{2}$ Jadi pada format terdahulu, pelanggaran ringan saja dapat berbuah sanksi yang bentuknya langsung pemecatan. Memperhatikan dampak dari pemecatan keanggotaan yang telah diuraikan di atas, meskipun bersifat sementara, tentu perlu dipikirkan bahwa sanksi pemecatan keanggotaan lebih pantas sebagai sanksi yang diberikan pada pelanggaran etika berat.

Bila mempertimbangkan bahwa bentuk sanksi berupa pemecatan keanggotaan dapat saja dijatuhkan pada suatu pelanggaran etika ringan maupun sedang berdasarkan Ortala MKEK 2008, maka jelas usulan sanksi 3 Orbit ini justru menjadi lebih ringan implikasinya pada mereka yang terbukti melakukan pelanggaran etik ringan maupun sedang, karena opsi-opsi sanksi yang ada di kategori 1 dan 2 tidaklah seberat implikasi dari pemecatan keanggotaan.

Bagaimana dengan mereka yang terbukti melakukan pelanggaran etika berat? Di Ortala MKEK 2008 jelas disebutkan bahwa pelanggar etika berat diberikan sanksi pemecatan keangggotaan selama 12 (duabelas) bulan. ${ }^{2}$ Sementara itu pada usulan perubahan ini, terpenting ditetapkan kategori sanksinya adalah pemecatan keanggotaan sementara, dengan memberikan fleksibilitas kepada para Majelis Pemeriksa untuk memilih kurun waktu pemecatan yang dirasa paling tepat sesuai kontekstualitas kasus antara 3-12 bulan. Di sini tampak bahwa 12 bulan merupakan ketetapan waktu pada Ortala MKEK sebelumnya, sementara 12 bulan pada usulan ini merupakan bagian dari kurun waktu maksimal yang dapat dijatuhkan, selain pemecatan keanggotaan tetap. Pemecatan keanggotaan tetap, sama seperti Ortala MKEK 2008, harus melalui pengesahan Muktamar dan umumnya setelah sebelumnya diberi sanksi kategori berat, namun dokter teradu tidak menunjukkan itikad baik dalam perkembangan menjalani sanksinya tersebut. Akibatnya, bila dibandingkan Ortala MKEK sebelumnya, sanksi ini relatif lebih ringan. Di sisi lain, kebijakan sanksi akumulatif ini justru memastikan bahwa selama dokter teradu tersebut menjalani pemecatan sementara, ia dapat mengisinya dengan betulbetul membentuk karakternya kembali melalui 
program-program pembinaan perilaku yang difasilitasi Divisi Pembinaan MKEK. Hal ini sebagaimana disinggung sebelumnya, merupakan roh dari peran MKEK dalam membina perilaku etis dan professional dari segenap dokter Indonesia.

\section{KESIMPULAN}

Kami mengusulkan pembagian sanksi etik menjadi tiga kategori: kategori 1 (pembinaan perilaku), kategori 2 (penginsafan tanpa pemecatan), dan kategori 3 (penginsafan dengan pemecatan sementara), yang cocok untuk masing-masing pelanggaran etik ringan, sedang, dan berat, serta sistem pemberlakuannya yang akumulatif. Hal ini sejalan dengan teori akumulasi dan eskalasi perilaku pelanggaran etik, lebih menjunjung keadilan, dan lebih sesuai dengan tujuan utama MKEK yang adalah pembinaan perilaku dan karakter dokter menjadi lebih mulia.

Jika usulan ini diterima, diperlukan tindak lanjut berupa perubahan Pedoman Organisasi dan Tatalaksana Kerja MKEK serta sosialisasi paradigma baru penerapan sanksi tersebut pada seluruh pemangku kebijakan, seluruh pengurus MKEK Pusat, Wilayah, dan Cabang serta Dewan Etik dan segenap pengurus Perhimpunan Dokter Spesialis/Pelayanan Primer (PDSp/ PDPP).

\section{KONFLIK KEPENTINGAN}

Tidak ada konflik kepentingan.

\section{REFERENSI}

1. Muktamar Ikatan Dokter Indonesia XXIX. Anggaran dasar dan anggaran rumah tangga Ikatan Dokter Indonesia. 2015.

2. Purwadianto A, editor. Pedoman organisasi dan tata laksana kerja Majelis Kehormatan Etik Kedokteran. Jakarta: Majelis Kehormatan Etika Kedokteran Ikatan Dokter Indonesia; 2008.
3. Rozaliyani A, Meilia PDI, Librianty N. Prinsip penetapan sanksi bagi pelanggaran etik kedokteran. J Etik Ked Ind. 2018 Mar 19;2(1):19. https://doi.org/10.26880/jeki.v2i1.11.

4. Majelis Kehormatan Etik Kedokteran Indonesia. Kode etik kedokteran tahun 2012. Jakarta; 2012.

5. Prawiroharjo P, Santosa F, Lefrandt R, Sidipratomo P, Purwadianto A. Dapatkah keputusan kemahkamahan etik Majelis Kehormatan Etik Kedokteran bersifat terbuka? J Etik Ked Ind. 2018 Jun 12;2(2):45. https:// doi.org/10.26880/jeki.v2i2.15. 